\title{
Cathepsin B Regulates Collagen Expression by Fibroblasts via Prolonging TLR2/NF- $\kappa$ B Activation
}

\author{
Xue Li, ${ }^{1}$ Zhou Wu, ${ }^{2,3}$ Junjun $\mathrm{Ni}^{2}{ }^{2}$ Yicong Liu, ${ }^{2}$ Jie Meng, ${ }^{2}$ Weixian Yu, ${ }^{1}$ \\ Hiroshi Nakanishi, ${ }^{2}$ and Yanmin Zhou ${ }^{1}$ \\ ${ }^{1}$ Department of Implantology, School of Stomatology, Jilin University, Changchun 130021, China \\ ${ }^{2}$ Department of Aging Science and Pharmacology, Faculty of Dental Science, Kyushu University, Fukuoka 812-8582, Japan \\ ${ }^{3}$ OBT Research Center, Faculty of Dental Science, Kyushu University, Fukuoka 812-8582, Japan
}

Correspondence should be addressed to Zhou Wu; zhouw@dent.kyushu-u.ac.jp and Yanmin Zhou; zhouym62@126.com

Received 25 May 2016; Revised 29 July 2016; Accepted 8 August 2016

Academic Editor: Juan F. Santibanez

Copyright (C) 2016 Xue Li et al. This is an open access article distributed under the Creative Commons Attribution License, which permits unrestricted use, distribution, and reproduction in any medium, provided the original work is properly cited.

\begin{abstract}
Fibroblasts are essential for tissue repair due to producing collagens, and lysosomal proteinase cathepsin B (CatB) is involved in promoting chronic inflammation. We herein report that CatB regulates the expression of collagens III and IV by fibroblasts in response to a TLR2 agonist, lipopolysaccharide from Porphyromonas gingivalis (P.g. LPS). In cultured human BJ fibroblasts, mRNA expression of CatB was significantly increased, while that of collagens III and IV was significantly decreased at $24 \mathrm{~h}$ after challenge with P.g. LPS $(1 \mu \mathrm{g} / \mathrm{mL})$. The P.g. LPS-decreased collagen expression was completely inhibited by CA-074Me, the specific inhibitor of CatB. Surprisingly, expression of collagens III and IV was significantly increased in the primary fibroblasts from CatB-deficient mice after challenge with P.g. LPS. The increase of CatB was accompanied with an increase of 8-hydroxy-2' -deoxyguanosine (8-OHdG) and a decrease of $\mathrm{I} \kappa \mathrm{B} \alpha$. Furthermore, the P.g. LPS-increased 8-OHdG and decreased $\mathrm{I} \kappa \mathrm{B} \alpha$ were restored by CA-074Me. Moreover, $87 \%$ of $\mathrm{CatB}$ and $86 \%$ of $8-\mathrm{OHdG}$ were colocalized with gingival fibroblasts of chronic periodontitis patients. The findings indicate the critical role of CatB in regulating the expression of collagens III and IV by fibroblasts via prolonging TLR2/NF- $\kappa \mathrm{B}$ activation and oxidative stress. CatB-specific inhibitors may therefore improve chronic inflammation-delayed tissue repair.
\end{abstract}

\section{Introduction}

Fibroblasts are essential for tissue repair due to their activity in producing collagens. Collagen can be divided into fibrillar and nonfibrillar families. Collagens I and III, the major fibrillar collagens in connective tissues, play important roles in tissue repair [1]. In particular, collagen III is suggested to regulate collagen I synthesis [2], as a higher ratio of collagen III to collagen I is associated with scarless wound healing in mammal models $[3,4]$, and collagen III-deficient mice exhibit more pronounced wound contracture than those with collagen III [5]. However, the expression of collagen III is regulated by the activity of local fibroblasts [6]. Collagen IV, a nonfibrillar collagen, is a major component of the basement membrane (BM) $[7,8]$. Recently, collagen IV has been shown to participate in the innate immune response by regulating cellular adhesion and migration [9], and Col4al (the human collagen IV gene) mutation-associated phenotypic features include chronic inflammation and immune activation [10$12]$.

Toll-like receptors (TLRs), which are expressed in fibroblasts $[13,14]$, have been observed to modulate tissue repair during chronic inflammation [15-17]. Furthermore, nuclear factor kappa B (NF- $\kappa \mathrm{B})$, the key transcription factor of TLR signaling, has been shown to inhibit collagen I gene expression directly [18] and mediate oxidative stress-decreased collagen biosynthesis [19].

Cathepsin B (CatB; EC 3.4.22.1), a typical cysteine lysosomal protease, promotes inflammation involved in the production of mature IL-1 $\beta$ [20-23]. CatB was recently found to be responsible for NF- $\kappa \mathrm{B}$ activation through autophagy degradation of inhibitor of $\kappa \mathrm{B} \alpha(\mathrm{I} \kappa \mathrm{B} \alpha)$ in microglia/macrophages [24]. Naturally, as a protease, CatB degrades collagens in fibroblasts [25], but the role of CatB in regulating collagen 
expression by fibroblasts during chronic inflammation is still unknown.

In the present study, we aimed to elucidate the involvement of CatB in the expression of collagens III and IV by fibroblasts after challenge with a TLR2 agonist, lipopolysaccharide from Porphyromonas gingivalis (P.g. LPS).

\section{Materials and Methods}

2.1. Reagents. P.g. LPS was purchased from InvivoGen (San Diego, CA, USA). Bay 11-7082 and SN50, the specific NF$\kappa \mathrm{B}$ inhibitors, were purchased from Sigma-Aldrich (St. Louis, MO, USA). CA-074Me, the specific CatB inhibitor, was purchased from Peptide Institute. Inc. (Osaka, Japan). Mouse anti-8-OHdG (N213120) was purchased from NOF Corporation (Kyoto, Japan). Antibodies of rabbit anti-fibronectin $(\mathrm{H}-300)$, goat anti-CatB (S-12), and rabbit anti-I $\kappa \mathrm{B} \alpha$ were purchased from Santa Cruz Biotechnology (Santa Cruz, CA, USA). Mouse anti-TLR2 (T 2.5) was purchased from eBioscience (San Diego, CA, USA). Mouse anti-Collagen III (Col-29) and mouse anti-Collagen IV (COL-94) were purchased from Abcam (Cambridge, UK).

2.2. Tissue Preparation from Periodontitis Patients. The gingival tissues were obtained from patients with periodontal surgery or extraction. The periodontal diagnosis of subjects with chronic periodontitis was established based on the clinical and radiographic criteria defined at the 1999 International World Workshop for a Classification of Periodontal Diseases and Conditions [26]. The samples included 7 cases diagnosed as chronic periodontitis (36-60 years of age, 3 males and 4 females), which were obtained from the Periodontology Department of the School of Stomatology, Jilin University. After periodontal surgery, the excised gingival specimens were immediately placed in liquid nitrogen and subsequently frozen at $-80^{\circ} \mathrm{C}$ until use in experiments.

The gingival samples were immersed in a periodate lysine paraformaldehyde (PLP) fixative consisting of $0.01 \mathrm{M}$ sodium metaperiodate, $0.075 \mathrm{M}$ L-lysine-HCL, $4 \%$ paraformaldehyde, and $0.03 \%$ phosphate buffer $(\mathrm{pH} 6.2)$ for $6 \mathrm{~h}$ at $4^{\circ} \mathrm{C}$. The specimens were protected for 2 days in $30 \%$ sucrose in phosphate-buffered saline (PBS) and then embedded in an optimal cutting temperature compound (Sakura Finetechnical Co., Ltd., Tokyo, Japan). The coronal frozen sections (thickness of $8 \mu \mathrm{m}$ ) were subjected to the immunohistochemical analyses.

2.3. BJ Human Fibroblast Cell Line Culture. BJ (CRL-2522) cells purchased from ATCC (Manassas, VA, USA) were cultured in Minimum Essential Medium (MEM; GIBCO, Grand Island, NY, USA) supplemented with 10\% fetal bovine serum (FBS, GIBCO), $1 \%$ penicillin-streptomycin, $10 \mu \mathrm{g} / \mathrm{mL}$ insulin, and $450 \mathrm{mg} / \mathrm{mL}$ glucose. The cells were cultured at $37^{\circ} \mathrm{C}$ in a humidified atmosphere with $5 \% \mathrm{CO}_{2}$.

\subsection{Primary CatB-Deficient (CatB ${ }^{-/-}$) Fibroblast Culture.} Three-day-old $\mathrm{CatB}^{-/-}$mice were sacrificed using an excessive amount of ether. The skin tissue was removed and immediately washed first in alcohol (75\%) and then in PBS.
The tissue was then cut and transferred into a 6-well plate. The fibroblasts were grown in MEM supplemented with $10 \%$ FBS, $1 \%$ penicillin-streptomycin, $10 \mu \mathrm{g} / \mathrm{mL}$ insulin, and $450 \mathrm{mg} / \mathrm{mL}$ glucose in a humidified atmosphere with $5 \% \mathrm{CO}_{2}$ at $37^{\circ} \mathrm{C}$. The medium was changed after five days, and then the cells were cultivated with culture medium in a new plate. The experiments were performed using early passage fibroblasts before the second passage.

2.5. Determination of Cell Viability. BJ cells were cultured in a 96-well plate for $24 \mathrm{~h}\left(5 \times 10^{3}\right.$ cells/well $)$ and then incubated with various concentrations of P.g. LPS for $48 \mathrm{~h}$. Cell viability was assessed using the cell-counting kit-8 (CCK-8; Dojindo, Kumamoto, Japan) in accordance with the manufacturer's instructions, as follows: After the treatment of P.g. LPS, $10 \mu \mathrm{L}$ CCK-8 was added to each well of the 96 -well plate and then incubated at $37^{\circ} \mathrm{C}$ for $2 \mathrm{~h}$. In accordance with the instructions, the optical density was read at a wavelength of $450 \mathrm{~nm}$ using the microplate reader. Cell viability was calculated using the following formula: optical density of treated group/control group $\times 100 \%$.

2.6. Immunofluorescence Imaging. The coronal frozen sections of periodontitis tissues were incubated with antibody diluent overnight at $4^{\circ} \mathrm{C}$. The sections were then treated with primary rabbit anti-fibronectin ( $\mathrm{H}-300,1: 1000)$, mouse anti8-OHdG (N213120, 1:1000), goat anti-CatB (S-12, 1:1000), and mouse anti-TLR2 (T 2.5, 1:1000) for $12 \mathrm{~h}$ at $4^{\circ} \mathrm{C}$. After washing with $\mathrm{PBS}$, the sections were incubated with a mixture of FITC-conjugated and rhodamine-conjugated secondary antibodies for $2 \mathrm{~h}$ at $24^{\circ} \mathrm{C}$. The sections were then washed again with PBS and mounted in Vectashield antifading medium (Vector Laboratory, CA, USA) and examined using a confocal laser scanning microscope (CLSM, C2si, Nikon, Japan). The CLSM images of individual sections were taken as a stack at a $1-\mu \mathrm{m}$ step size in the $z$-direction with $20 \mathrm{x}$ objectives (numerical aperture $=0.5$ ), zoom factor 1.0. A rectangle $(1024 \times 1024$ pixels $)$ corresponding to the size of 450 $\times 450 \mu \mathrm{m}$ was used as the counting frame. The CLSM images were shown as the middle of the stacked images.

For the cultured BJ fibroblasts staining, the cells were seeded at $5 \times 10^{5}$ cells $/ \mathrm{mL}$ in 24 -well plates. $48 \mathrm{~h}$ after P.g. LPS $(1 \mu \mathrm{g} / \mathrm{mL})$ challenge or pretreatment with CA-074Me, the cells were fixed with $4 \%$ paraformaldehyde and then incubated with the mouse anti-p65 (1:500) and mouse anti-8OHdG $(1: 1000)$ overnight at $4^{\circ} \mathrm{C}$. After being incubated with anti-mouse Alexa 488 (1:1000, Jackson Immunoresearch Lab. Inc.) at room temperature for $2 \mathrm{~h}$, they were then incubated with Hoechst (1:200, Sigma-Aldrich, Japan) and mounted in the antifading medium Vectashield. Fluorescence images were taken using a CLSM (C2si, Nikon, Japan).

2.7. Real-Time Quantitative Polymerase Chain Reaction Analysis (RT-qPCR). BJ cells were treated with P.g. LPS $(1 \mu \mathrm{g} / \mathrm{mL})$ for $3,12,24$, and $48 \mathrm{~h}$; primary $\mathrm{CatB}^{-/-}$fibroblast cells and primary wild type fibroblasts were treated with $P . g$. LPS $(1 \mu \mathrm{g} / \mathrm{mL})$ for 24 and $48 \mathrm{~h}$. After treatment, the cells were collected. A set of the BJ cells was pretreated with Bay 11-7082 (20 $\mu \mathrm{M},[27]), \mathrm{CA}-074 \mathrm{Me}(50 \mu \mathrm{M},[22])$, or SN50 (20 $\mu \mathrm{M})$ for 
$1 \mathrm{~h}$ and then treated with P.g. LPS $(1 \mu \mathrm{g} / \mathrm{mL})$, incubated for 48 $\mathrm{h}$, and harvested.

mRNA isolated from these cells was subjected to RTqPCR. The total RNA was extracted with the Purelink RNA microkit (Invitrogen, Tokyo, Japan) in accordance with the manufacturer's instructions. A total of $1000 \mathrm{ng}$ of extracted RNA was reverse transcribed to cDNA using the High Capacity RNA-to-cDNA Master Mix (Applied Biosystems, Foster City, CA, USA). The thermal cycling was held at $95^{\circ} \mathrm{C}$ for $5 \mathrm{~min}$, followed by 40 cycles at $95^{\circ} \mathrm{C}$ for $5 \mathrm{sec}$ and at $60^{\circ} \mathrm{C}$ for $10 \mathrm{sec}$. The cDNA was amplified in duplicate using TaqMan Universal PCR Master Mix (Applied Biosystems) with an Applied Biosystems 7500/7500 Fast Real-Time PCR System. The data were evaluated using the 7500 software program (version 2.0, Applied Biosystems). The primer sequences used were as follows: Human Actin: $5^{\prime}$-AGA GCT ACG AGC TGC CTG AC- $3^{\prime}$ and $5^{\prime}$-AGC ACT GTG TTG GCG TAC AG3'; Human TLR2: $5^{\prime}$-GCC AAA GTC TTG ATT GAT TGG$3^{\prime}$ and $5^{\prime}$-TTG AAG TTC TCC AGC TCC TG-3'; Human Collagen III: $5^{\prime}$-TGG TGT TGG AGC CGC TGC CA- $3^{\prime}$ and $5^{\prime}$-CTC AGC ACT AGA ATC TGT CC-3'; Human Collagen IV: $5^{\prime}$-ATG TCA ATG GCA CCC ATC AC- $3^{\prime}$ and $5^{\prime}$-CTT CAA GGT GGA CGG CGT AG-3'; Human CatB: $5^{\prime}$-TGA CGT GTT GGT ACA CTC CTG- $3^{\prime}$ and $5^{\prime}$-TGG AGG GAG CTT TCT CTG TG-3' ${ }^{\prime}$; Mouse Actin: $5^{\prime}$-CAA TAG TGA TGA CCT GGC CGT- $3^{\prime}$ and $5^{\prime}$-AGA GGG AAA TCG TGC GTG AC- $3^{\prime}$; Mouse Collagen III: $5^{\prime}$-CCA GCT GGG CCT TTG ATA CCT- $3^{\prime}$ and $5^{\prime}$-TGC CCA CAG CCT TCT ACA CCT$3^{\prime}$; and Mouse Collagen IV: $5^{\prime}$-AGG CAG GTC AAG TTC TAG CG- $3^{\prime}$ and ${ }^{\prime}{ }^{\prime}$-CAA GCA TAG TGG TCC GAG TC- $3^{\prime}$. For data normalization, an endogenous control (actin) was assessed to control for the cDNA input, and the relative units were calculated by a comparative Ct method. All of the RTqPCR experiments were repeated three times, and the results are presented as the means of the ratios \pm the standard error of the mean (SEM).

2.8. Electrophoresis and Immunoblotting. BJ cells were cultured in the 6-well plate at a density of $5 \times 10^{5}$ cells $/ \mathrm{mL}$. After treatment with P.g. LPS $(1 \mu \mathrm{g} / \mathrm{mL})$ for 12,24 , and $48 \mathrm{~h}$, the cells were collected for experiments. A set of the BJ cells was pretreated with CA-074Me $(50 \mu \mathrm{M})$ for $1 \mathrm{~h}$, and then P.g. LPS $(1 \mu \mathrm{g} / \mathrm{mL})$ was added to the medium. The cells continued to be cultured for $48 \mathrm{~h}$ and were then harvested.

The cells were electrophoresed in $7.5 \%$ or $12 \%$ SDSpolyacrylamide gels, and the proteins on the SDS gels were transferred electrophoretically to nitrocellulose membranes, which were washed with PBS and then blocked for $1 \mathrm{~h}$. The membranes were incubated with one of the following primary antibodies overnight at $4^{\circ} \mathrm{C}$ : rabbit anti- $\mathrm{I} \kappa \mathrm{B} \alpha(1: 1000)$, mouse anti-TLR2 (1:1000), rabbit anti-collagen III $(1: 500)$, rabbit anti-collagen IV $(1: 500)$ or goat anti-CatB $(1: 1000)$. After washing the membranes with PBS, the membranes were incubated with horseradish peroxidase- (HRP-) labeled antirabbit $(1: 1000$, GE Healthcare, UK), anti-mouse $(1: 1000$, GE Healthcare, UK), or anti-goat (1:1000, GE Healthcare, $\mathrm{UK}$ ) antibodies for $2 \mathrm{~h}$ at $24^{\circ} \mathrm{C}$, and then the protein bands were detected by an enhanced chemiluminescence detection system (ECK kit, Thermo Scientific, Rockford, IL, USA) using an image analyzer (LAS-4000; Fuji Photo Film, Tokyo, Japan).

2.9. 8-OHdG Assay. BJ cells were cultured in the $10 \mathrm{~cm}$ dish at a density of $5 \times 10^{5}$ cells $/ \mathrm{mL}$. After the cells adhering to the bottom of the dish, P.g. LPS $(1 \mu \mathrm{g} / \mathrm{mL})$ was treated or pretreated with CA-074Me $(50 \mu \mathrm{M})$ for $1 \mathrm{~h}$. After $48 \mathrm{~h}$, the cells were collected and subjected to DNA extraction by DNA Extractor TIS Kit (Wako, Osaka, Japan) according to the manufacturer's protocol. The extracted DNA were calculated and prepared according to 8-OHdG Assay Preparation Reagent Set (Wako, Osaka, Japan), $200 \mu \mathrm{g} / 150 \mu \mathrm{L}$ of each sample were heated at $98^{\circ} \mathrm{C}$ for $2 \mathrm{~min}$. After chill in ice for $5 \mathrm{~min}$, the samples were incubated with $19 \mu \mathrm{L}$ acetic buffer and $10 \mu \mathrm{L}$ of nuclease P1 solution at $37^{\circ} \mathrm{C}$ for $30 \mathrm{~min} .20 \mu \mathrm{L}$ of Tris buffer and $1 \mu \mathrm{L}$ of Alkaline Phosphatase solution were added and incubated at $37^{\circ} \mathrm{C}$ for $30 \mathrm{~min}$. Then, the samples were subjected to 8-OHdG ELISA kit (High sensitive-8OHdG check; Japan Institute for the Control of Aging, Fukuroi, Japan) following the manufacturer's protocol.

2.10. Data Analysis. The data are represented as the means \pm SEM. The statistical analyses were performed using a oneor two-way analysis of variance (ANOVA) with a post hoc Tukey's test using the GraphPad Prism software package (GraphPad Software Inc., San Diego, CA, USA). A value of $P<0.05$ was considered to indicate statistical significance.

\section{Results}

3.1. The Expression of CatB as well as Collagen III and Collagen IV after P.g. LPS Challenge. First, we examined the suitable concentrations of P.g. LPS for challenging the cultured human BJ fibroblasts. The cell viability of BJ fibroblasts decreased significantly at $48 \mathrm{~h}$ after challenge with $1000 \mu \mathrm{g} / \mathrm{mL}$ P.g. LPS (Figure 1(a)). We therefore decided to use the concentration of P.g. LPS at $1 \mu \mathrm{g} / \mathrm{mL}$ in subsequent experiments, which was one-thousandth of the concentration that reduced the cell viability for the time course of the experiments.

During the time courses $(3,12,24$, and $48 \mathrm{~h})$ challenged with P.g. LPS $(1 \mu \mathrm{g} / \mathrm{mL})$, the mean mRNA expression of CatB was significantly increased at 24 and $48 \mathrm{~h}$ (the late culture periods) but not at 3 or $12 \mathrm{~h}$ (the early culture periods) compared with the unchallenged cells (Figure 1(b)). In contrast, the mean mRNA expression of collagens III and IV was significantly increased at 3 and $12 \mathrm{~h}$ but was significantly decreased at 24 and $48 \mathrm{~h}$ after challenge with P.g. LPS compared with the unchallenged cells (Figures 1(c) and 1(d)). These observations provided the first evidence for a negative link between CatB and collagens III and IV during chronic activation of TLR2 signaling.

3.2. The Regulation of Collagens III and IV Expression by CatB in Fibroblasts after P.g. LPS Challenge. We next examined the roles of CatB in regulating the expression of collagens III and IV after challenge with P.g. LPS via two approaches: pharmacological inhibition using the specific CatB inhibitor $\mathrm{CA}-074 \mathrm{Me}$ and genetic deletion of $\mathrm{CatB}$ using primary fibroblasts from CatB-deficient $\left(\mathrm{CatB}^{-/-}\right)$mice. 


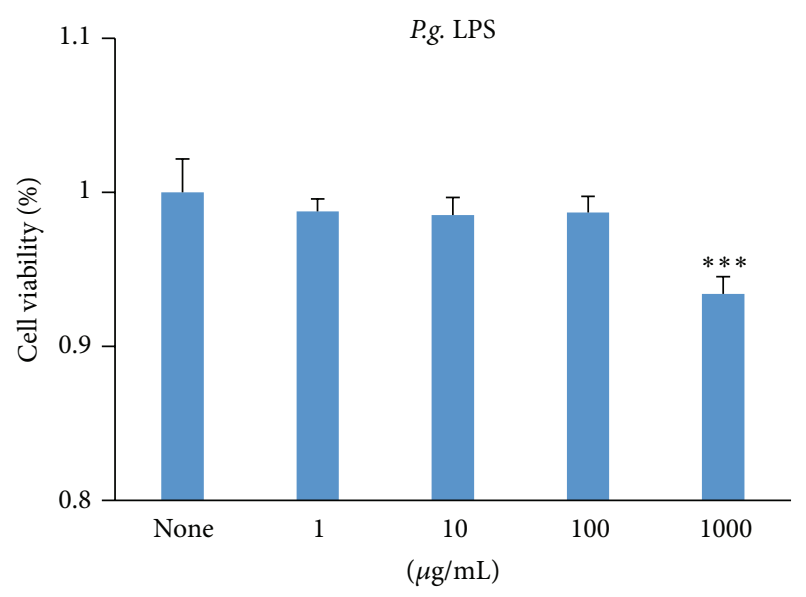

(a)

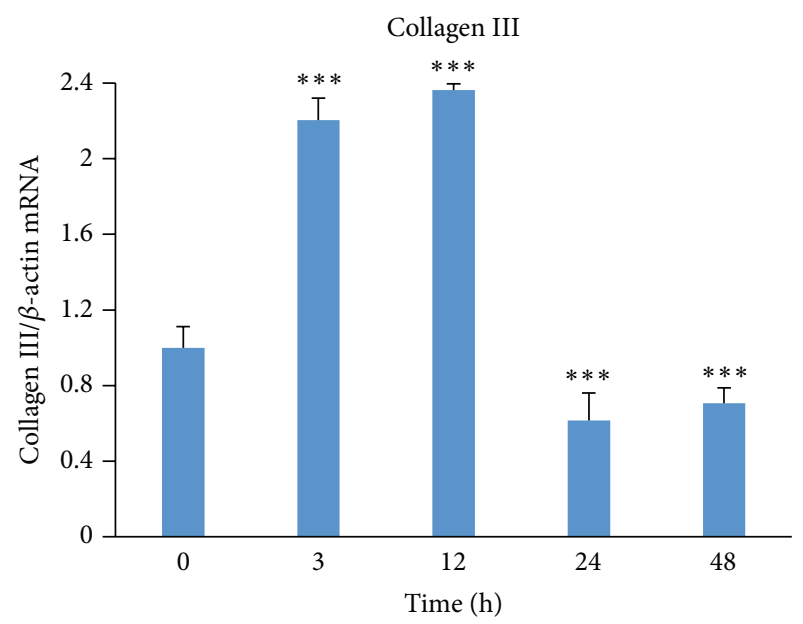

(c)

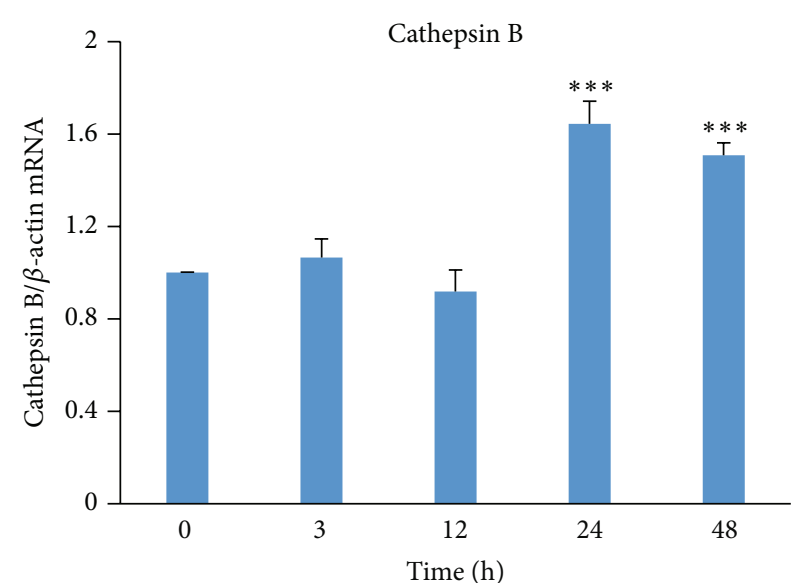

(b)

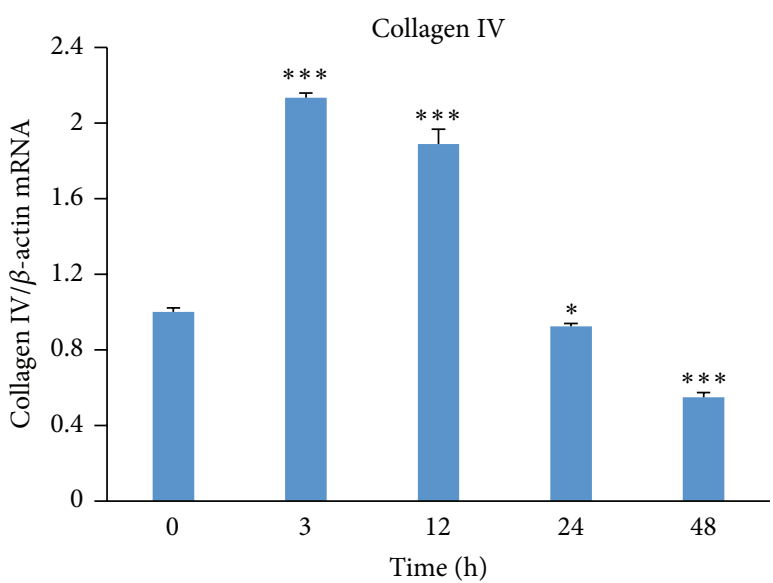

(d)

FIgURE 1: Expression of CatB and collagens III and IV by BJ fibroblasts after challenge with P.g. LPS. (a) The cell viability of BJ fibroblasts at $48 \mathrm{~h}$ after challenge with different dose of P.g. LPS by using cell-counting kit-8. (b) The mean mRNA expression level of CatB (3, 12, 24, and $48 \mathrm{~h})$ after challenge with P.g. LPS $(1 \mu \mathrm{g} / \mathrm{mL})$. (c) The mean mRNA expression level of collagen III $(3,12,24$, and $48 \mathrm{~h})$ after challenge with P.g. LPS $(1 \mu \mathrm{g} / \mathrm{mL})$. (d) The mean mRNA expression level of collagen IV $(3,12,24$, and $48 \mathrm{~h})$ after challenge with P.g. LPS $(1 \mu \mathrm{g} / \mathrm{mL})$. Each column and bar represent the mean \pm SEM $(n=4$ each). The asterisks indicate a statistically significant difference from the value at the start of experiments $(0 \mathrm{~h})\left({ }^{*} \mathrm{P}<0.05,{ }^{* * *} \mathrm{P}<0.001\right)$.

Pretreatment with CA-074Me $(50 \mu \mathrm{M}, 1 \mathrm{~h})$ was able to restore the mean mRNA expression of both collagens III and IV to control levels at $48 \mathrm{~h}$ after challenge with P.g. LPS (Figures 2(a) and 2(b)). The protein expression levels of collagens III and IV were also restored by pretreatment with CA-074Me $(50 \mu \mathrm{M}, 1 \mathrm{~h})$ after $48 \mathrm{~h}$ challenge with P.g. LPS (Figures 2(c)-2(e)). In the primary fibroblasts from wild type mice, the mean mRNA expression of collagens III and IV was significantly decreased at 24 and $48 \mathrm{~h}$ after challenge with P.g. LPS, findings which were consistent with those observed in human BJ fibroblasts (Figures 1(c) and 1(d)). To our surprise, the mean mRNA expression of collagens III and IV in the primary fibroblasts from $\mathrm{CatB}^{-1-}$ mice was significantly increased compared with that of wild type mice at 24 and $48 \mathrm{~h}$ after challenge with P.g. LPS (Figures 2(f) and $2(\mathrm{~g})$ ). These observations clearly demonstrate that CatB has a critical role in regulating the expression of collagens
III and IV by fibroblasts during chronic activation of TLR2 signaling.

3.3. The Regulation of NF- $\kappa B$ Activation and Oxidative Damage for Decreasing Collagens III and IV by CatB after P.g. LPS Challenge. Next, we investigated the molecular mechanisms by which CatB regulates the expression of collagens III and IV by fibroblasts after P.g. LPS challenge. Pretreatment with Bay 11-7082 or SN50, the specific inhibitors of NF- $\kappa$ B (1 h before P.g. LPS challenge), was able to inhibit the P.g. LPSinduced decrease in the mean mRNA expression of collagens III and IV by BJ fibroblasts at $48 \mathrm{~h}$ (Figures 3(a) and 3(b)), demonstrating that the P.g. LPS-induced decrease in the collagens was dependent on NF- $\kappa \mathrm{B}$ activation. These results were consistent with those of a previous report showing that collagen I gene expression was dependent on NF- $\kappa \mathrm{B}$ activation [18]. 


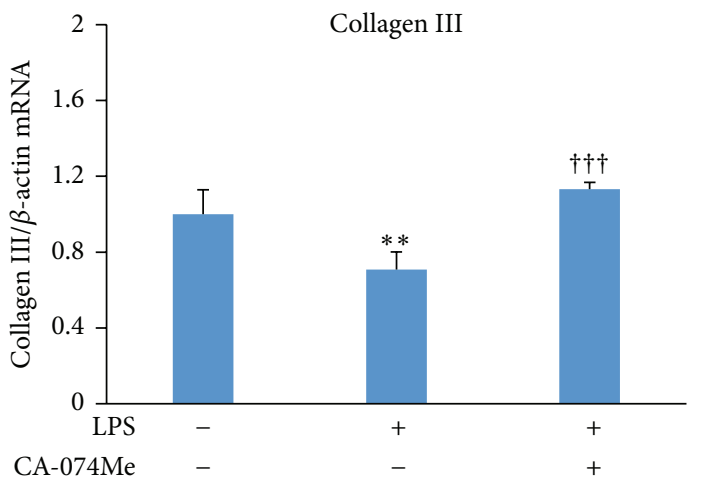

(a)

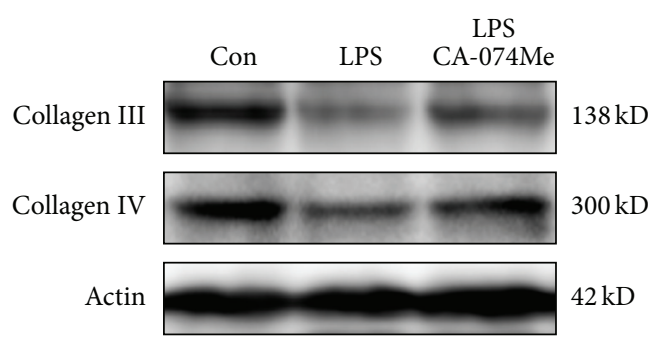

(c)

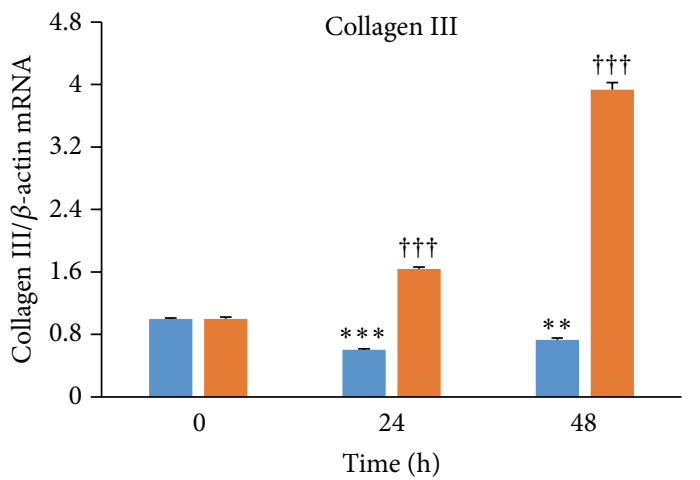

WT

$\mathrm{CatB}^{-/-}$

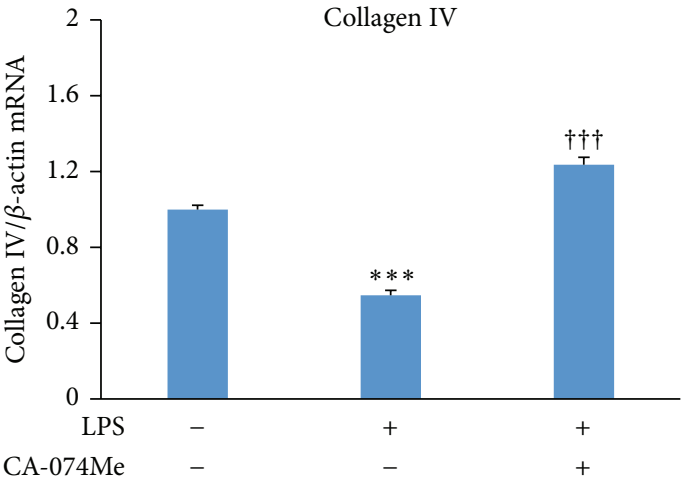

(b)

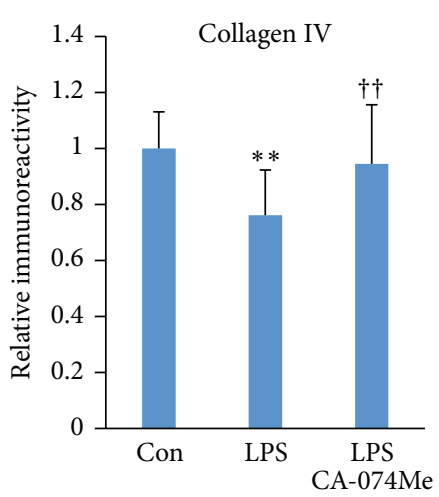

(e)

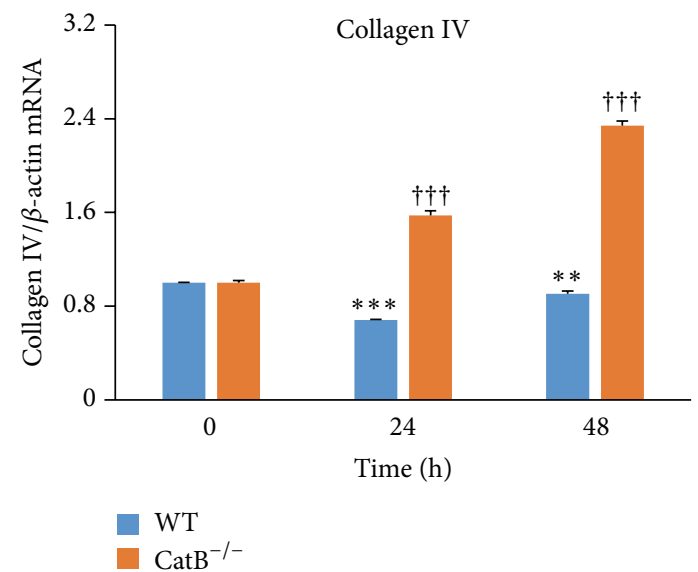

(g)

FIGURE 2: The effects of CatB on the expression of collagens III and IV by BJ fibroblasts after challenge with P.g. LPS. (a) The effect of CA074Me $(50 \mu \mathrm{M}, 1 \mathrm{~h}$ before P.g. LPS challenge) on the expression of collagen III at $48 \mathrm{~h}$ after challenge with P.g. LPS (1 $\mu \mathrm{g} / \mathrm{mL})$. (b) The effect of CA-074Me on the expression of collagen IV at $48 \mathrm{~h}$ after challenge with $P . g$. LPS $(1 \mu \mathrm{g} / \mathrm{mL})$. Each column and bar represent the mean \pm SEM ( $n=4$ each). The asterisks indicate a statistically significant difference from the value in untreated cells $\left({ }^{* *} P<0.01,{ }^{* * *} P<0.001\right)$. The crosses indicate a statistically significant difference from the value in P.g. LPS-challenged cells without pretreatment with CA- $074 \mathrm{Me}\left({ }^{\dagger \dagger \dagger} P<0.001\right)$. (c) The effect of CA-074Me on the protein expression of collagen III and collagen IV at $48 \mathrm{~h}$ after challenge with P.g. LPS (1 $\mu \mathrm{g} / \mathrm{mL})$. ((d), (e)) The quantitative analyses of the immunoblotting for collagen III (d) and collagen IV (e). Each column and bar represent the mean \pm SEM ( $n=4$ each). The asterisks indicate a statistically significant difference from the value in untreated cells $\left({ }^{* *} P<0.01\right)$. The crosses indicate a statistically significant difference from the value in P.g. LPS-challenged cells without pretreatment with CA-074Me $\left({ }^{\dagger} P<0.05,{ }^{\dagger \dagger} P<0.01\right)$. (f) The expression of collagen III in the primary fibroblasts from wild type and CatB ${ }^{-/}$mice at 24 and $48 \mathrm{~h}$ after challenge with P.g. LPS $(1 \mu \mathrm{g} / \mathrm{mL})$. (g) The expression of collagen IV in the primary fibroblasts from wild type and CatB ${ }^{-/-}$mice at 24 and $48 \mathrm{~h}$ after challenge with P.g. LPS $(1 \mu \mathrm{g} / \mathrm{mL})$. Each column and bar represent the mean \pm SEM $(n=4$ each $)$. The asterisks indicate a statistically significant difference from the value in unchallenged cells from wild type mice $\left({ }^{* *} P<0.01,{ }^{* * *} P<0.001\right)$. The crosses indicate a statistically significant difference from the value in the unchallenged cells from $\mathrm{CatB}^{-/-}$mice $\left({ }^{\dagger \dagger \dagger} \mathrm{P}<0.001\right)$. 


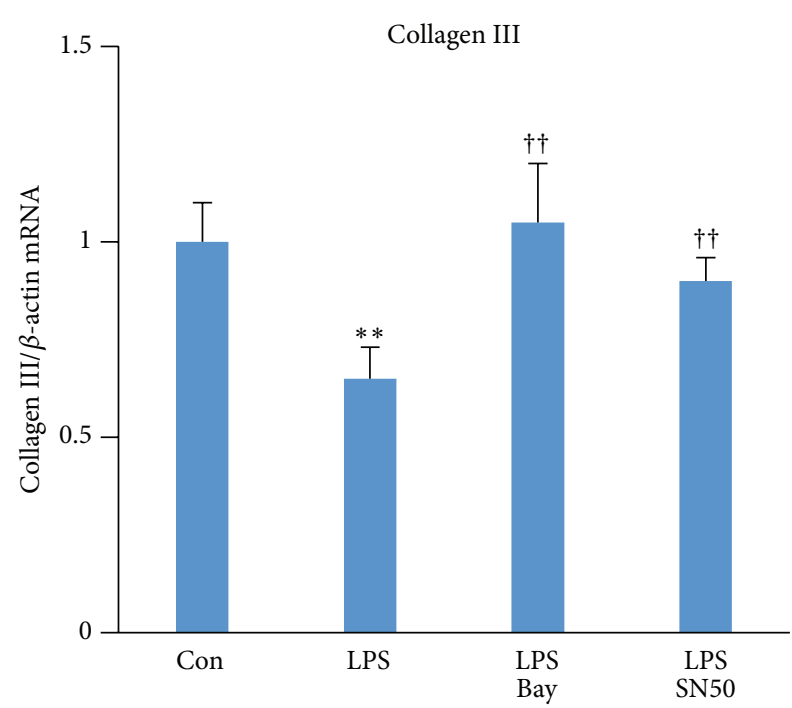

(a)

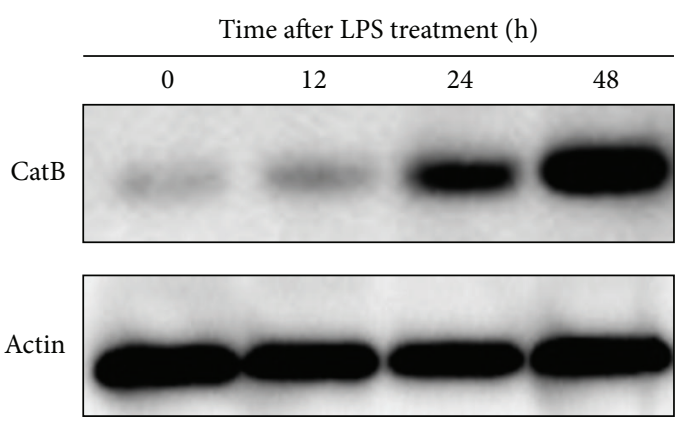

(c)

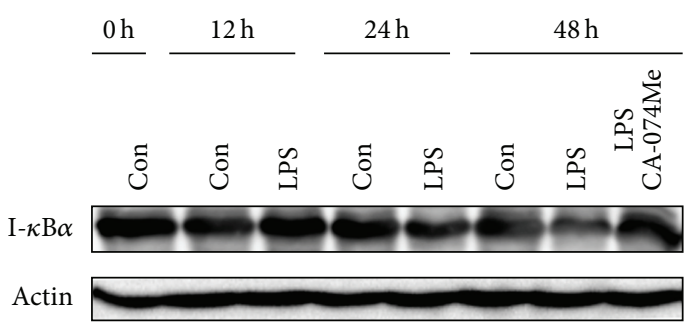

(e)

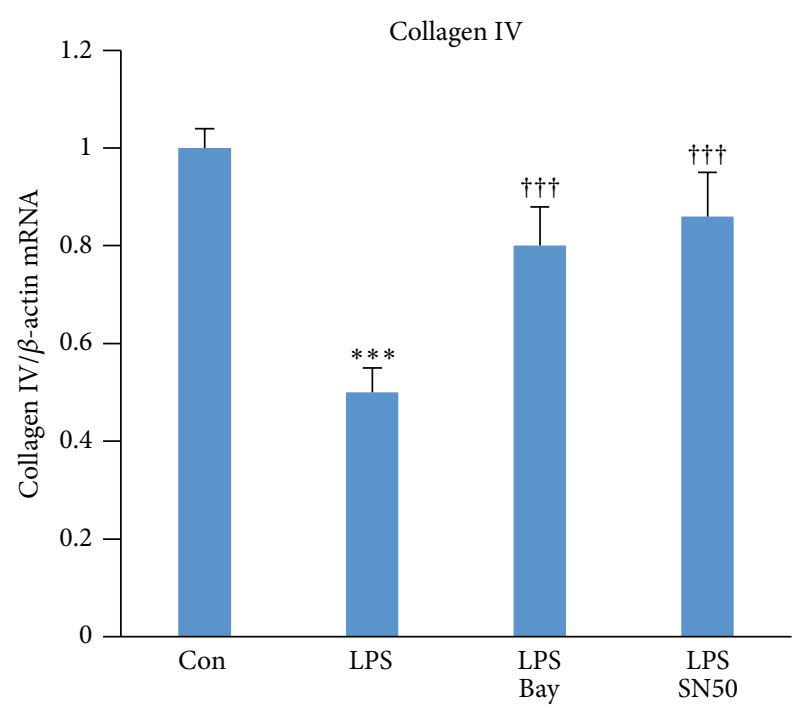

(b)

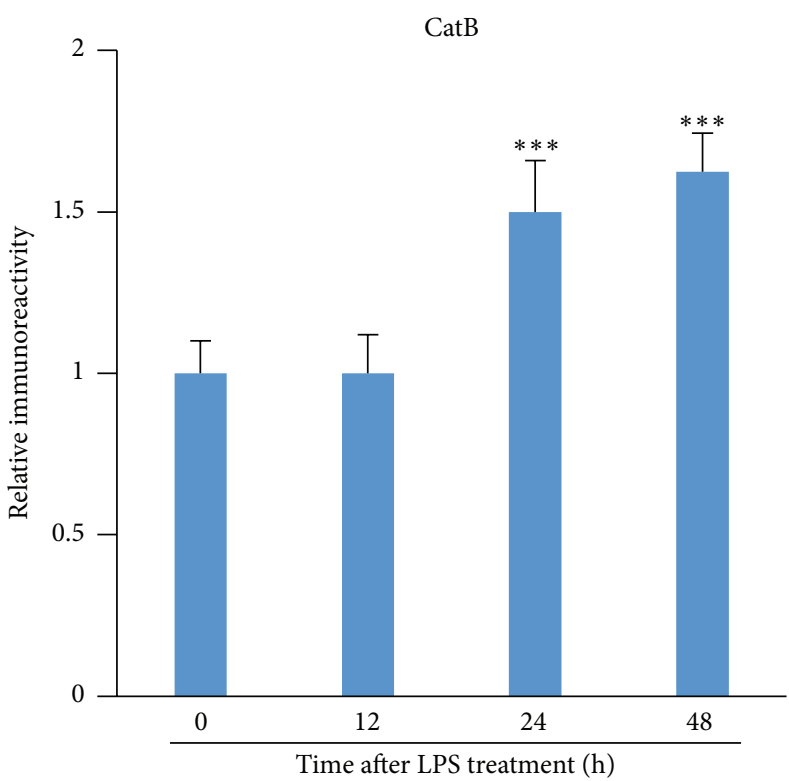

(d)

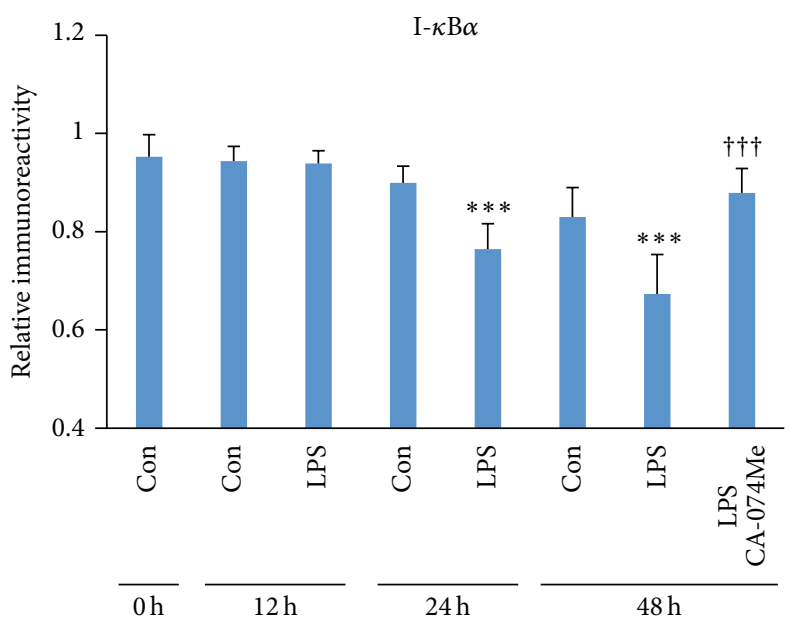

(f)

FIGURE 3: Continued. 


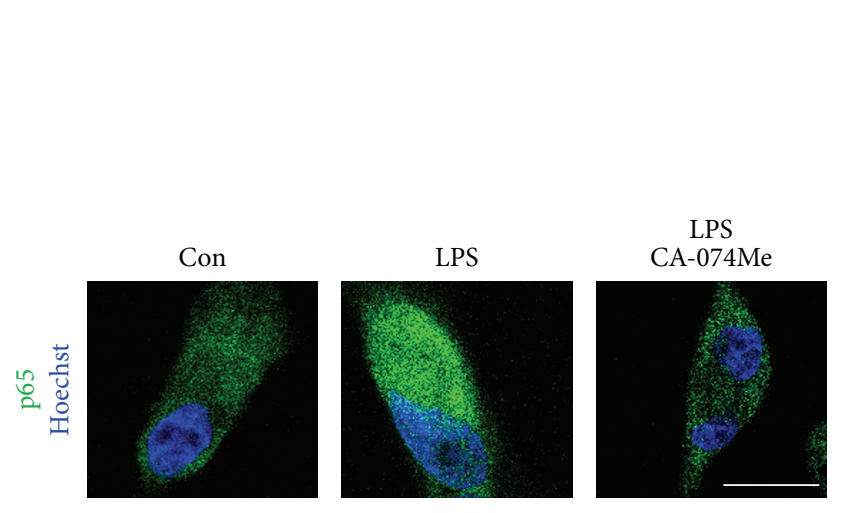

(g)

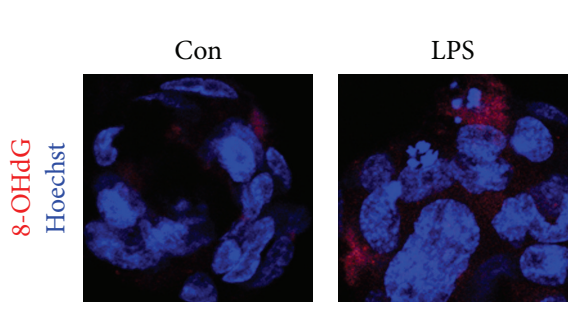

(i)
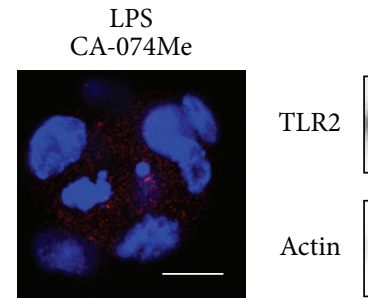

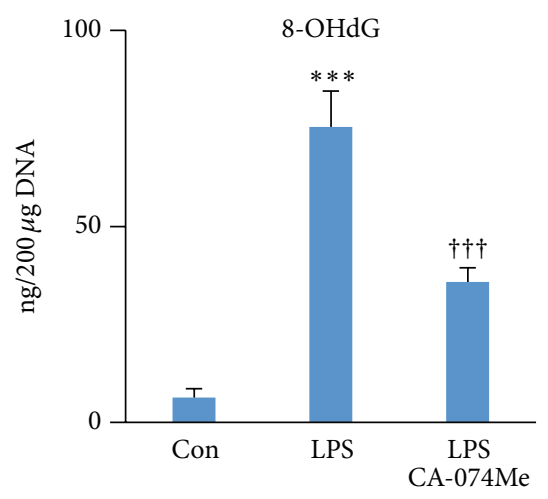

(h)

Con

LPS

LPS

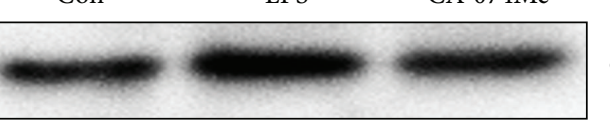

$90 \mathrm{kD}$

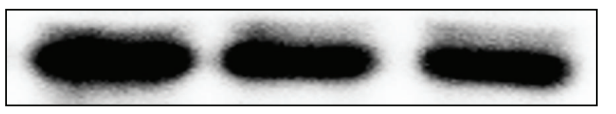

$42 \mathrm{kD}$

(j)

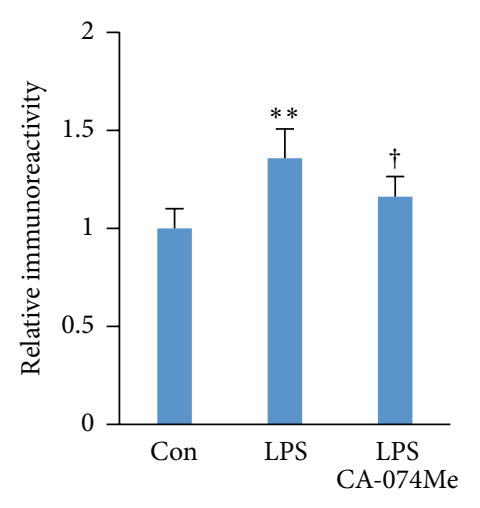

(k)

Figure 3: The effects of CatB on NF- $\kappa \mathrm{B}$ activation and oxidative damage in BJ fibroblasts after challenge with P.g. LPS. ((a), (b)) The effect of Bay 11-7082 (Bay, $20 \mu \mathrm{M}, 1 \mathrm{~h}$ before P.g. LPS challenge) and SN50 $(20 \mu \mathrm{M}, 1 \mathrm{~h}$ before P.g. LPS challenge) on the expression of collagen III (a) and collagen IV (b) at $48 \mathrm{~h}$ after challenge with P.g. LPS $(1 \mu \mathrm{g} / \mathrm{mL})$. Each column and bar represent the mean \pm SEM $(n=4$ each). The asterisks indicate a statistically significant difference from the value in unchallenged cells $\left({ }^{* *} P<0.01,{ }^{* * *} P<0.001\right)$. The crosses indicate a statistically significant difference from the value in P.g. LPS-challenged cells without pretreatment with Bay $11-7082\left({ }^{\dagger \dagger} P<0.01,{ }^{\dagger \dagger} P<0.001\right)$. (c) The time course of the protein expression of CatB in BJ fibroblasts after challenge with P.g. LPS $(1 \mu \mathrm{g} / \mathrm{mL})$. (d) The quantitative analyses of the immunoblotting for CatB. Each column and bar represent the mean $\pm \operatorname{SEM}(n=4$, each). The asterisks indicate a statistically significant difference from the value in the unchallenged cells $\left({ }^{* * *} P<0.001\right)$. (e) The time course of the protein expression of I $\kappa \mathrm{B} \alpha$ in $\mathrm{BJ}$ fibroblasts after challenge with P.g. LPS $(1 \mu \mathrm{g} / \mathrm{mL})$. (f) The quantitative analyses of the immunoblotting for $\mathrm{I} \kappa \mathrm{B} \alpha$. Each column and bar represent the mean $\pm \operatorname{SEM}\left(n=4\right.$, each). The asterisks indicate a statistically significant difference from the value in the unchallenged cells $\left({ }^{* * *} P<0.001\right)$. The crosses indicate a statistically significant difference from the value in $48 \mathrm{~h} P . g$. LPS-challenged cells without pretreatment with CA-074Me $\left({ }^{\dagger \dagger} P<0.001\right)$. (g) The immunofluorescent CLSM images of $\mathrm{p} 65$ (green) in BJ fibroblasts after $48 \mathrm{~h}$ challenged with P.g. LPS or pretreatment with CA-074Me. Scale bar $=10 \mu \mathrm{m}$. (h) The amount of $8-\mathrm{OHdG}$ in BJ fibroblasts $48 \mathrm{~h}$ after challenge with P.g. LPS. Each column and bar represent the mean \pm SEM $(n=4$, each). The asterisks indicate a statistically significant difference from the value in the unchallenged cells $\left({ }^{* * *} P<0.001\right)$. The crosses indicate a statistically significant difference from the value in $48 \mathrm{~h} P . g$. LPS-challenged cells without pretreatment with CA-074Me $\left({ }^{\dagger \dagger \dagger} P<0.001\right)$. (i) The immunofluorescent CLSM images of 8-OHdG (green) in BJ fibroblasts after $48 \mathrm{~h}$ challenged with P.g. LPS or pretreatment with CA-074Me. Scale bar $=10 \mu \mathrm{m}$. (j) The protein expression of TLR2 in BJ fibroblasts $48 \mathrm{~h}$ after challenge with P.g. LPS $(1 \mu \mathrm{g} / \mathrm{mL})$. (k) The quantitative analyses of the immunoblotting for TLR2 in (j). Each column and bar represent the mean \pm SEM $(n=4$, each). The asterisks indicate a statistically significant difference from the value in the unchallenged cells $\left({ }^{* *} P<0.01\right)$. The crosses indicate a statistically significant difference from the value in $48 \mathrm{~h} P$.g. LPS-challenged cells without pretreatment with CA- $074 \mathrm{Me}\left({ }^{\dagger} P<0.05\right)$. 

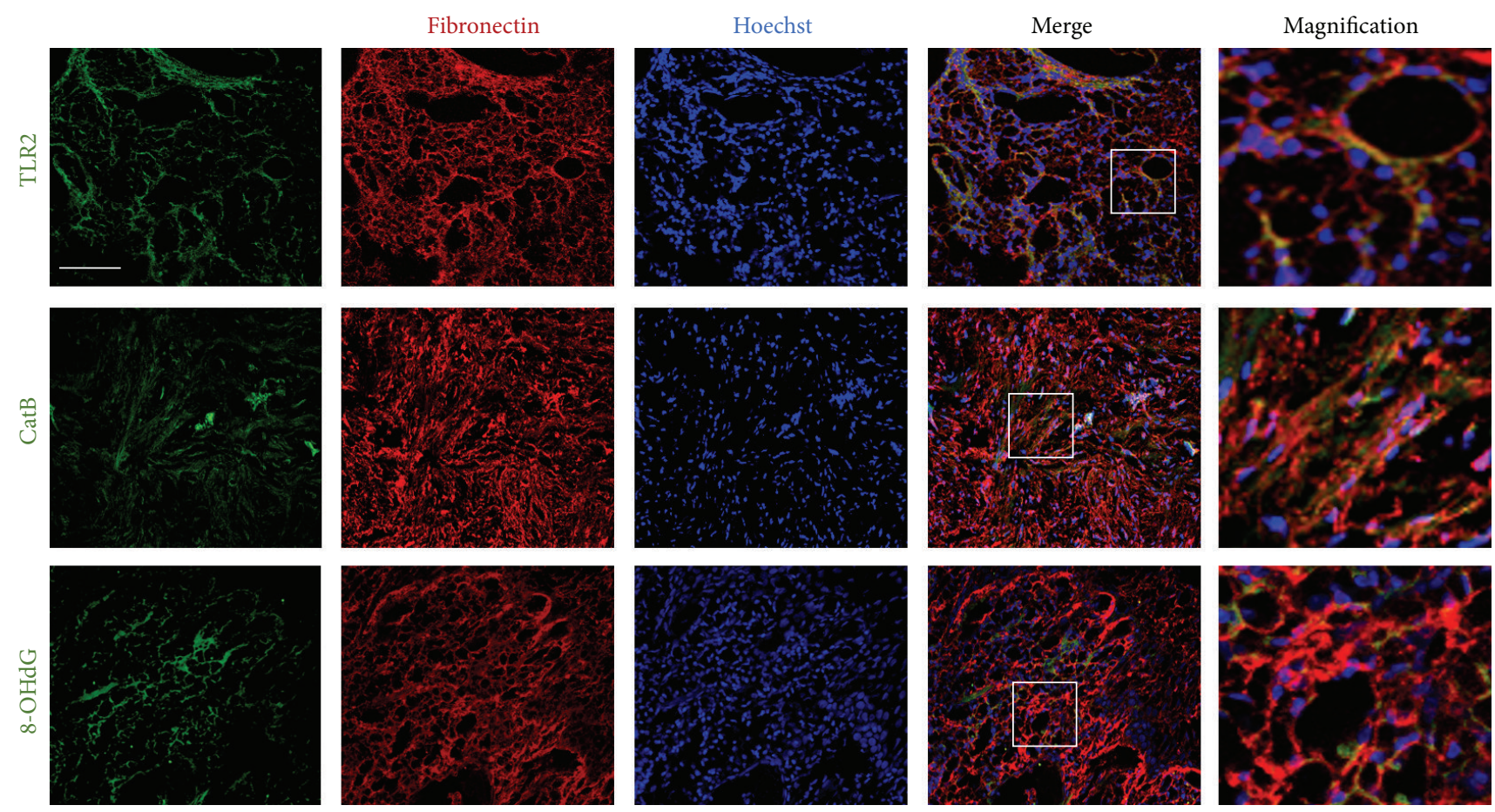

Figure 4: The immunofluorescent CLSM images of TLR2, CatB, and 8-OHdG (green) with fibronectin (red) and Hoechst-stained nuclei (blue) in the inflamed tissues of patients with chronic periodontitis. Scale bar $=50 \mu \mathrm{m}$. The magnifical images are made from the square areas. The increased CatB is closely related to the oxidative damage during the chronic activation of TLR2/NF- $\kappa \mathrm{B}$ signaling.

We then further analyzed the expression of $\mathrm{Cat} B, \mathrm{I} \kappa \mathrm{B} \alpha$, and 8-OHdG (a critical biomarker of oxidative stress). The mean expression of CatB was significantly increased at 24 and $48 \mathrm{~h}$ (Figures $3(\mathrm{c})$ and $3(\mathrm{~d})$ ), while the mean expression of $\mathrm{I} \kappa \mathrm{B} \alpha$ was significantly decreased compared with that of the control group at 24 and $48 \mathrm{~h}$ after P.g. LPS challenge (Figures 3(e) and 3(f)). The mean expression of the P.g. LPSdecreased $I \kappa B \alpha$ was paralleled with the significant increase in the nuclear localization of $\mathrm{p} 65 \mathrm{NF}-\kappa \mathrm{B}$ at 24 after P.g. LPS challenge (Figure $3(\mathrm{~g})$ ). The mean amount of $8-\mathrm{OHdG}$ was significantly increased at $48 \mathrm{~h}$ (Figure $3(\mathrm{~h})$ ) and the protein expression level of TLR 2 was also increased at $48 \mathrm{~h}$ after P.g. LPS challenge (Figures $3(\mathrm{j})$ and $3(\mathrm{k})$ ). These results suggest that an elevated level of CatB is positively associated with NF$\kappa \mathrm{B}$ activation and oxidative damage after challenge with P.g. LPS.

Interestingly, the P.g. LPS-induced increase in levels of 8 -OHdG and decrease in levels of $\mathrm{I} \kappa \mathrm{B} \alpha$ were significantly inhibited by CA-074Me at $48 \mathrm{~h}$ after P.g. LPS challenge (Figures 3(e)-3(i)). These observations demonstrate that CatB is involved in the proteolytic degradation of the $\mathrm{I} \kappa \mathrm{B} \alpha$ and oxidative DNA damage during chronic P.g. LPS challenge. Therefore, the novel mechanism of CatB in regulating the expression of collagens by fibroblasts is via chronically activating TLR2/NF- $\kappa$ B signaling and subsequent oxidative damage.

3.4. Determination of CatB and Oxidative Damage in Fibroblasts of Inflamed Tissues with Chronic Periodontitis. TLR2, $\mathrm{Cat} \mathrm{B}$, and $8-\mathrm{OHdG}$ were expressed in the fibroblasts of inflamed tissues with chronic periodontitis and found to be localized in $89 \%, 87 \%$, and $86 \%$ of fibronectin-positive fibroblasts, respectively (Figure 4). These results further demonstrate that the increased $\mathrm{CatB}$ is involved in oxidative damage in inflammatory tissues via the chronic activation of TLR2/NF- $\kappa$ B signaling. The critical role and novel mechanism of CatB in regulating the expression of collagens by fibroblasts via this activation and oxidative damage were summarized in Figure 5.

\section{Discussion}

The major finding of the present study was clarifying the critical role of $\mathrm{CatB}$ in regulating collagen expression by fibroblasts via prolonging TLR2/NF- $\kappa \mathrm{B}$ activation (summarized in Figure 5). To our knowledge, this is the first study to demonstrate the involvement of CatB in collagen expression during chronic inflammation and oxidative stress, thereby adding to the available information regarding the mechanisms of delayed tissue repair during chronic inflammation.

We focused on collagens III and IV in fibroblasts because of their importance in wound healing and tissue remodeling. As the main fibrillar collagens in connective tissues [1], collagen III is suggested to regulate collagen I synthesis [2], since collagen III-deficit mice exhibit more pronounced wound contracture than those with collagen III [5], and upregulating collagen III expression using natural remedies accelerates cutaneous wound healing in rats [6]. However, the expression of collagen III is regulated by the activity of local fibroblasts [6]. Collagen IV, as a major component of 


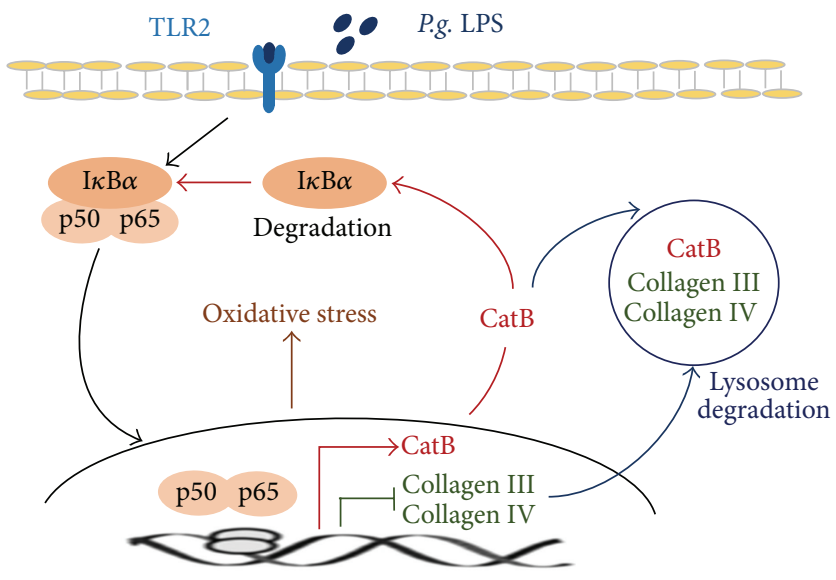

FIGURE 5: A schematic representation of the effects and the novel molecular mechanisms of CatB in regulating the expression of collagens III and IV via chronic activation of TLR2/NF- $\kappa$ B signaling and subsequent oxidative damage.

the $\mathrm{BM}$, participates in the inflammatory responses during tissue repair $[7,28,29]$, principally via cellular regulation and migration $[9,30]$. Indeed, Col4al (human collagen IV gene) mutation-associated phenotypic features include chronic inflammation and immune activation $[10,11]$.

In the present study, the significant increase in the mRNA expression of collagens III and IV in fibroblasts at 3 and $12 \mathrm{~h}$ (the early culture periods) might have been a definitive response to challenge with the pathogenic agent TLR2 agonist P.g. LPS during the acute activation of TLR2 signaling [27], further demonstrating the expression of TLR2 in fibroblasts $[13,14]$. In contrast, the mRNA expressions of both collagens III and IV in fibroblasts were significantly decreased at 24 and $48 \mathrm{~h}$ (the late culture periods) after challenge with P.g. LPS, possibly due to the chronic activation of TLR2 signaling. The concentration of P.g. LPS $(1 \mu \mathrm{g} / \mathrm{mL})$ used in the present experiments was one-thousandth of the concentration that reduced cell viability $(1000 \mu \mathrm{g} / \mathrm{mL})$, indicating that the P.g. LPS-induced decreases in collagen expression occurred in living fibroblasts (Figure 1(a)).

Of note, the P.g. LPS-induced decreases in collagen III and IV reflected the P.g. LPS-induced decrease in expression of $\mathrm{I} \kappa \mathrm{B} \alpha$ and increase in expression of $8-\mathrm{OHdG}$. However, the P.g. LPS-induced decreases in expression of collagens were completely restored by Bay 11-7082 and SN50, the specific inhibitor of NF- $\kappa \mathrm{B}$ (Figures $3(\mathrm{a})$ and $3(\mathrm{~b})$ ), suggesting that these reductions in collagen expression were dependent on $\mathrm{NF}-\kappa \mathrm{B}$ activation and oxidative damage, given that activated $\mathrm{NF}-\kappa \mathrm{B}$ exacerbates oxidative stress [31]. These results are consistent with a previous finding that NF- $\kappa \mathrm{B}$ activation is necessary for UVC-decreased collagen biosynthesis [19] and that NF- $\kappa \mathrm{B}$ inhibits collagen I gene expression [18]. The present findings suggest that TLR $2 / \mathrm{NF}-\kappa \mathrm{B}$-dependent decreases in the expression of collagen by fibroblasts may result in delayed tissue repair during chronic inflammation.

Elevated levels of $\mathrm{CatB}$ in fibroblasts are typically observed in many chronic inflammatory diseases, including rheumatoid arthritis as well as periodontitis [32-34]. Increased $\mathrm{CatB}$ expression in fibroblasts leads to tissue destruction, as fibroblasts are the prominent resident cells in the soft connective tissues [35]. In the present study, we determined that P.g. LPS increased the expression of CatB in fibroblasts, similar to the previous findings in macrophages [36]. Of note, the increased expression of CatB mRNA in the fibroblasts was observed at 24 and $48 \mathrm{~h}$ but not at 3 or $12 \mathrm{~h}$ after challenge with P.g. LPS, which agreed with the previous finding that $\mathrm{CatB}$ levels were not increased in the acute and intermediate stages of bacterial infection [37], implying that Cat B expression in fibroblasts might be induced by chronic activation of TLR2 signaling. Importantly, the P.g. LPS-induced increase in the CatB mRNA expression was paralleled by a P.g. LPS-induced decrease in the mRNA expression of both collagens III and IV, but this decrease was completely restored by pretreatment with CA-074Me. Surprisingly, the mean mRNA expression of collagens III and IV was significantly increased in the primary fibroblasts from $\mathrm{CatB}^{-/-}$mice from $24 \mathrm{~h}$ after challenge with P.g. LPS. The findings demonstrate the critical role of CatB in regulating collagen expression by fibroblasts during chronic activation of TLR2 signaling. CatB in P.g. LPS-challenged fibroblasts may not be involved in apoptosis [38], as the cell viabilities were not reduced with a P.g. LPS-induced increase in the expression of CatB. In addition, we also detected the expression of CatB in fibroblasts in the inflamed periodontal tissues from patients with chronic periodontitis (Figure 4), which was consistent with the findings in patients with rheumatoid arthritis [39, 40], inflammatory bowel disease [41], and polymyositis [42]. However, neither collagen III nor collagen IV was detected in these inflamed periodontal tissues (data not shown), strongly suggesting that CatB critically regulates collagen expression by fibroblasts during chronic inflammation.

CatB was recently found to regulate $N F-\kappa B$ activation [24]. However, conversely, CatB expression is believed to be NF- $\kappa \mathrm{B}$-dependent as the promoter of CatB has NF- $\kappa \mathrm{B}$ binding site [43]. In almost all cell types, including fibroblasts, $\mathrm{NF}-\kappa \mathrm{B}$ exists as a dimer of a p50 and p65 subunit that is retained in an inactive cytoplasmic complex by binding to 
the $\mathrm{I} \kappa \mathrm{B} \alpha . \mathrm{NF}-\kappa \mathrm{B}$ can be activated by TLR2 agonists as well as proinflammatory molecules, such as IL- $1 \beta$, which induce phosphorylation acutely and proteolytic degradation of the $\mathrm{I} \kappa \mathrm{B}$ subunit chronically [21]. In the present study, an analysis of the whole cell extracts showed that the P.g. LPS-induced $\mathrm{I} \kappa \mathrm{B} \alpha$ degradation in fibroblasts was paralleled by a P.g. LPSinduced increase in $\mathrm{CatB}$ in the late culture period; furthermore, the P.g. LPS-induced $\mathrm{I} \kappa \mathrm{B} \alpha$ degradation was prevented by CA-074Me pretreatment (Figure 3 ). These results coincide with our previous observation of CatB-dependent $\mathrm{I} \kappa \mathrm{B} \alpha$ degradation in microglia in a hypoxia/ischemia model [24] and strongly suggest that $\mathrm{Cat} B$ is involved in the proteolytic degradation of the $\mathrm{I} \kappa \mathrm{B}$ subunit for slowing the migration out of the NF- $\kappa$ B complex from the nucleus, leading to sustained $\mathrm{NF}-\kappa \mathrm{B}$ activation in response to chronic P.g. LPS challenge.

This is the first report to clarify the novel mechanism of CatB involved in the downregulation of collagens III and IV via chronic activation of TLR $2 / N F-\kappa B$ signaling. Furthermore, the P.g. LPS-induced increase in $8-\mathrm{OHdG}$ might have been prevented by $\mathrm{CA}-074 \mathrm{Me}$, suggesting the possible involvement of $\mathrm{Cat} B$ in promoting oxidative stress through prolonging $\mathrm{NF}-\kappa \mathrm{B}$ activation, as activated $\mathrm{NF}-\kappa \mathrm{B}$ exacerbates oxidative stress [31].

CatB is considered a major lysosomal cysteine protease for the degradation of collagen in soft connective tissues, as it possesses both endopeptidase and exopeptidase activity which differs from other lysosomal cysteine proteases [44]. The increased expression of CatB by the chronic activation of TLR2/NF- $\kappa$ B signaling may also be involved in degrading the intercellular and extracellular collagen produced by fibroblasts, as CatB activities are required for the degradation of intracellular and extracellular collagen IV [45]. Furthermore, CatB is known to activate other collagenolytic matrix metalloproteinases for collagen degradation in fibroblasts at elevated levels during chronic inflammation [46].

\section{Conclusion}

CatB regulates the expression of collagens III and IV by fibroblasts via prolonging TLR $2 / \mathrm{NF}-\kappa \mathrm{B}$ activation and oxidative stress (schematic illustration in Figure 5). Considering the role of CatB in collagen expression, CatBspecific inhibitors may be a useful approach for improving inflammation-delayed connective tissue repair, such as that found in dermatitis and periodontitis.

\section{Competing Interests}

The authors declare that they have no conflict of interests in association with this study.

\section{Authors' Contributions}

Xue Li and Zhou Wu contributed equally to this work.

\section{Acknowledgments}

This work was supported partly by The National Natural Science Foundation of China to Yanmin Zhou (81570983) and Grants-in-Aid for Scientific Research to Zhou Wu (16K11478).

\section{References}

[1] L. E. Tracy, R. A. Minasian, and E. J. Caterson, "Extracellular matrix and dermal fibroblast function in the healing wound," Advances in Wound Care, vol. 5, no. 3, pp. 119-136, 2016.

[2] X. Liu, T. H. Chang, S. M. Levenson, and M. Rojkind, "Wound fluids from saline solution- and Staphylococcus aureus peptidoglycan-inoculated sponges induce expression of matrix metalloproteinase 13 messenger ribonucleic acid by cultured rat fibroblasts," Wound Repair and Regeneration, vol. 5, no. 4, pp. 348-354, 1997.

[3] R. Carter, K. Jain, V. Sykes, and D. Lanning, "Differential expression of procollagen genes between mid- and late-gestational fetal fibroblasts," Journal of Surgical Research, vol. 156, no. 1, pp. 90-94, 2009.

[4] L. Cuttle, M. Nataatmadja, J. F. Fraser, M. Kempf, R. M. Kimble, and M. T. Hayes, "Collagen in the scarless fetal skin wound: detection with picrosirius-polarization," Wound Repair and Regeneration, vol. 13, no. 2, pp. 198-204, 2005.

[5] S. W. Volk, Y. Wang, E. A. Mauldin, K. W. Liechty, and S. L. Adams, "Diminished type III collagen promotes myofibroblast differentiation and increases scar deposition in cutaneous wound healing," Cells Tissues Organs, vol. 194, no. 1, pp. 25-37, 2011.

[6] M. Ganeshkumar, T. Ponrasu, R. Krithika, K. Iyappan, V. S. Gayathri, and L. Suguna, "Topical application of Acalypha indica accelerates rat cutaneous wound healing by up-regulating the expression of Type I and III collagen," Journal of Ethnopharmacology, vol. 142, no. 1, pp. 14-22, 2012.

[7] O. Chovar-Vera, V. Valenzuela-Muñoz, and C. GallardoEscárate, "Molecular characterization of collagen IV evidences early transcription expression related to the immune response against bacterial infection in the red abalone (Haliotis rufescens)," Fish and Shellfish Immunology, vol. 42, no. 2, pp. 241248, 2015.

[8] W. J. Lennarz and M. D. Lane, Encyclopedia of Biological Chemistry, Academic Press, Cambridge, Mass, USA, 2013.

[9] K. Kühn, "Basement membrane (type IV) collagen," Matrix Biology, vol. 14, no. 6, pp. 439-445, 1995.

[10] M. Kiss, A. A. Kiss, M. Radics et al., "Drosophila type IV collagen mutation associates with immune system activation and intestinal dysfunction," Matrix Biology, vol. 49, pp. 120-131, 2016.

[11] D. S. Kuo, C. Labelle-Dumais, and D. B. Gould, "COL4A1 and COL4A2 mutations and disease: insights into pathogenic mechanisms and potential therapeutic targets," Human Molecular Genetics, vol. 21, no. 1, pp. R97-R110, 2012.

[12] J.-H. Ryu, S.-H. Kim, H.-Y. Lee et al., "Innate immune homeostasis by the homeobox gene Caudal and commensal-gut mutualism in Drosophila," Science, vol. 319, no. 5864, pp. 777$782,2008$.

[13] P. Proost, A.-K. Vynckier, F. Mahieu et al., "Microbial Toll-like receptor ligands differentially regulate CXCL10/IP-10 expression in fibroblasts and mononuclear leukocytes in synergy with IFN- $\gamma$ and provide a mechanism for enhanced synovial chemokine levels in septic arthritis," European Journal of Immunology, vol. 33, no. 11, pp. 3146-3153, 2003. 
[14] S. Hamidi, M. Schäfer-Korting, and G. Weindl, "TLR2/1 and sphingosine 1-phosphate modulate inflammation, myofibroblast differentiation and cell migration in fibroblasts," Biochimica et Biophysica Acta-Molecular and Cell Biology of Lipids, vol. 1841, no. 4, pp. 484-494, 2014.

[15] P. Huebener and R. F. Schwabe, "Regulation of wound healing and organ fibrosis by toll-like receptors," Biochimica et Biophysica Acta-Molecular Basis of Disease, vol. 1832, no. 7, pp. 10051017, 2013

[16] M. Wu, D. J. Schneider, M. D. Mayes et al., "Osteopontin in systemic sclerosis and its role in dermal fibrosis," Journal of Investigative Dermatology, vol. 132, no. 6, pp. 1605-1614, 2012.

[17] S. Bhattacharyya, K. Kelley, D. S. Melichian et al., "Toll-like receptor 4 signaling augments transforming growth factor- $\beta$ responses: a novel mechanism for maintaining and amplifying fibrosis in scleroderma," The American Journal of Pathology, vol. 182, no. 1, pp. 192-205, 2013.

[18] D. J. Kouba, K.-Y. Chung, T. Nishiyama et al., "Nuclear factor- $\kappa \mathrm{B}$ mediates TNF- $\alpha$ inhibitory effect on $\alpha 2$ (I) collagen (COL1A2) gene transcription in human dermal fibroblasts," Journal of Immunology, vol. 162, no. 7, pp. 4226-4234, 1999.

[19] L. Szoka, E. Karna, and J. A. Palka, "UVC inhibits collagen biosynthesis through up-regulation of NF- $\kappa \mathrm{B}$ p 65 signaling in cultured fibroblasts," Journal of Photochemistry and Photobiology B: Biology, vol. 129, pp. 143-148, 2013.

[20] A. Halle, V. Hornung, G. C. Petzold et al., "The NALP3 inflammasome is involved in the innate immune response to amyloid- $\beta$," Nature Immunology, vol. 9, no. 8, pp. 857-865, 2008.

[21] K. Terada, J. Yamada, Y. Hayashi et al., "Involvement of cathepsin $B$ in the processing and secretion of interleukin- $1 \beta$ in chromogranin a-stimulated microglia," Glia, vol. 58, no. 1, pp. 114-124, 2010.

[22] L. Sun, Z. Wu, Y. Hayashi et al., "Microglial cathepsin B contributes to the initiation of peripheral inflammation-induced chronic pain," The Journal of Neuroscience, vol. 32, no. 33, pp. 11330-11342, 2012.

[23] Z. Wu, L. Sun, S. Hashioka et al., "Differential pathways for interleukin $-1 \beta$ production activated by chromogranin $A$ and amyloid $\beta$ in microglia," Neurobiology of Aging, vol. 34, no. 12, pp. 2715-2725, 2013.

[24] J. Ni, Z. Wu, C. Peterts, K. Yamamoto, H. Qing, and H. Nakanishi, "The critical role of proteolytic relay through cathepsins B and $\mathrm{E}$ in the phenotypic change of microglia/macrophage," The Journal of Neuroscience, vol. 35, no. 36, pp. 12488-12501, 2015.

[25] P. D. Arora, M. F. Manolson, G. P. Downey, J. Sodek, and C. A. G. McCulloch, "A novel model system for characterization of phagosomal maturation, acidification, and intracellular collagen degradation in fibroblasts," The Journal of Biological Chemistry, vol. 275, no. 45, pp. 35432-35441, 2000.

[26] G. C. Armitage, "Development of a classification system for periodontal diseases and conditions," Annals of Periodontology, vol. 4, no. 1, pp. 1-6, 1999.

[27] Y. Liu, Z. Wu, X. Zhang et al., "Leptomeningeal cells transduce peripheral macrophages inflammatory signal to microglia in reponse to Porphyromonas gingivalis LPS," Mediators of Inflammation, vol. 2013, Article ID 407562, 11 pages, 2013.

[28] B. Altincicek and A. Vilcinskas, "Metamorphosis and collagenIV-fragments stimulate innate immune response in the greater wax moth, Galleria mellonella," Developmental and Comparative Immunology, vol. 30, no. 12, pp. 1108-1118, 2006.
[29] A. M. Abreu Velez and M. S. Howard, "Diagnosis and treatment of cutaneous paraneoplastic disorders," Dermatologic Therapy, vol. 23, no. 6, pp. 662-675, 2010.

[30] N. Ortega and Z. Werb, "New functional roles for noncollagenous domains of basement membrane collagens," Journal of Cell Science, vol. 115, part 22, pp. 4201-4214, 2002.

[31] H. L. Pahl, "Activators and target genes of Rel/NF- $\kappa$ B transcription factors," Oncogene, vol. 18, no. 49, pp. 6853-6866, 1999.

[32] G. Tettamanti, A. Grimaldi, L. Rinaldi et al., "The multifunctional role of fibroblasts during wound healing in Hirudo medicinalis (Annelida, Hirudinea)," Biology of the Cell, vol. 96, no. 6, pp. 443-455, 2004.

[33] S. W. Cox, B. M. Eley, M. Kiili, A. Asikainen, T. Tervahartiala, and T. Sorsa, "Collagen degradation by interleukin- $1 \beta$ stimulated gingival fibroblasts is accompanied by release and activation of multiple matrix metalloproteinases and cysteine proteinases," Oral Diseases, vol. 12, no. 1, pp. 34-40, 2006.

[34] B. Tong, B. Wan, Z. Wei et al., "Role of cathepsin B in regulating migration and invasion of fibroblast-like synoviocytes into inflamed tissue from patients with rheumatoid arthritis," Clinical and Experimental Immunology, vol. 177, no. 3, pp. 586597, 2014.

[35] P. Geraghty, M. P. Rogan, C. M. Greene et al., "Neutrophil elastase up-regulates cathepsin B and matrix metalloprotease2 expression," Journal of Immunology, vol. 178, no. 9, pp. 58715878, 2007.

[36] J. Hannaford, H. Guo, and X. Chen, "Involvement of cathepsins $\mathrm{B}$ and $\mathrm{L}$ in inflammation and cholesterol trafficking protein NPC2 secretion in macrophages," Obesity, vol. 21, no. 8, pp. 1586-1595, 2013.

[37] I. S. Cha, J. Kwon, J. Y. Mun et al., "Cathepsins in the kidney of olive flounder, Paralichthys olivaceus, and their responses to bacterial infection," Developmental and Comparative Immunology, vol. 38, no. 4, pp. 538-544, 2012.

[38] A. Canbay, A. E. Feldstein, H. Higuchi et al., "Kupffer cell engulfment of apoptotic bodies stimulates death ligand and cytokine expression," Hepatology, vol. 38, no. 5, pp. 1188-1198, 2003.

[39] G. Cunnane, O. Fitzgerald, C. Beeton, T. E. Cawston, and B. Bresnihan, "Early joint erosions and serum levels of matrix metalloproteinase 1, matrix metalloproteinase 3, and tissue inhibitor of metalloproteinases 1 in rheumatoid arthritis," Arthritis \& Rheumatism, vol. 44, no. 10, pp. 2263-2274, 2001.

[40] T. Mishiro, S. Nakano, S. Takahara et al., "Relationship between cathepsin B and thrombin in rheumatoid arthritis," The Journal of Rheumatology, vol. 31, no. 7, pp. 1265-1273, 2004.

[41] A. Baici, K. Müntener, A. Willimann, and R. Zwicky, "Regulation of human cathepsin B by alternative mRNA splicing: homeostasis, fatal errors and cell death," Biological Chemistry, vol. 387, no. 8, pp. 1017-1021, 2006.

[42] Y. Feng, L. Ni, and Q. Wang, "Administration of cathepsin B inhibitor CA-074Me reduces inflammation and apoptosis in polymyositis," Journal of Dermatological Science, vol. 72, no. 2, pp. 158-167, 2013.

[43] S. Bien, C. A. Ritter, M. Gratz et al., "Nuclear factor- $\kappa$ B mediates up-regulation of cathepsin B by doxorubicin in tumor cells," Molecular Pharmacology, vol. 65, no. 5, pp. 1092-1102, 2004.

[44] L. B. Creemers, I. D. C. Jansen, K. A. Hoeben, W. Beertsen, and V. Everts, "Involvement of V-ATPases in the digestion of soft connective tissue collagen," Biochemical and Biophysical Research Communications, vol. 251, no. 2, pp. 429-436, 1998. 
[45] A. Mitrović, B. Mirković, I. Sosič, S. Gobec, and J. Kos, "Inhibition of endopeptidase and exopeptidase activity of cathepsin B impairs extracellular matrix degradation and tumour invasion," Biological Chemistry, vol. 397, no. 2, pp. 164-174, 2016.

[46] L. Zhang, J. Lin, J. Guo, W. Sun, and L. Pan, "Effects of 1, $25-(\mathrm{OH}) 2 \mathrm{D} 3$ on airway remodeling and airway epithelial cell apoptosis in a murine model of asthma," Zhonghua Yi Xue Za Zhi, vol. 95, no. 48, pp. 3945-3949, 2015. 


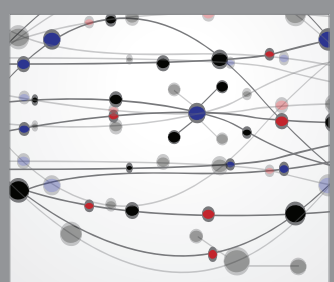

The Scientific World Journal
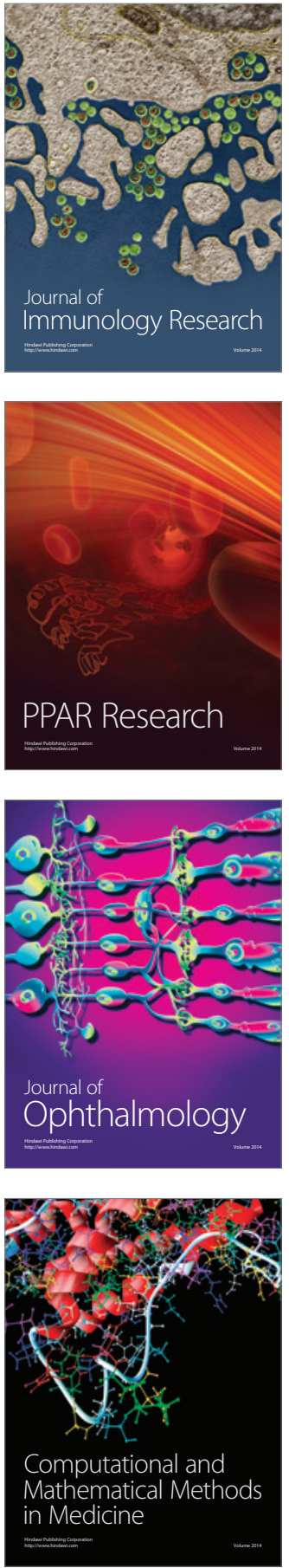

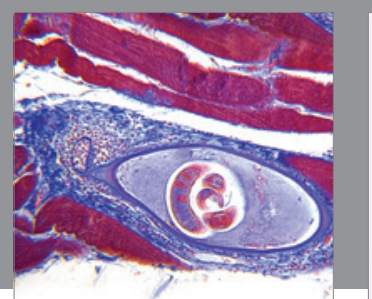

Gastroenterology Research and Practice

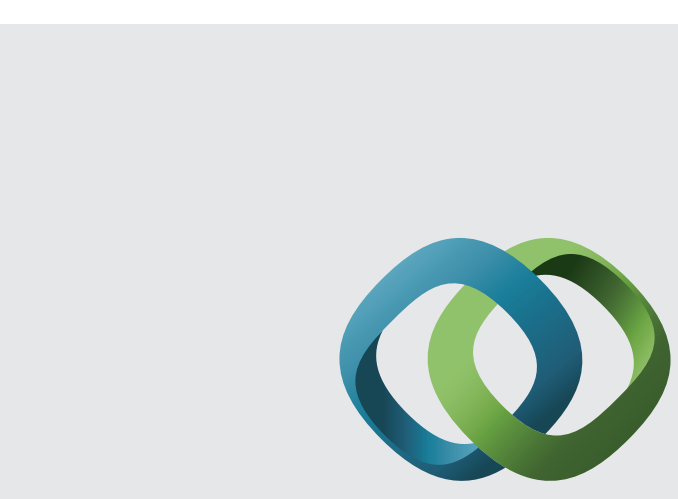

\section{Hindawi}

Submit your manuscripts at

http://www.hindawi.com
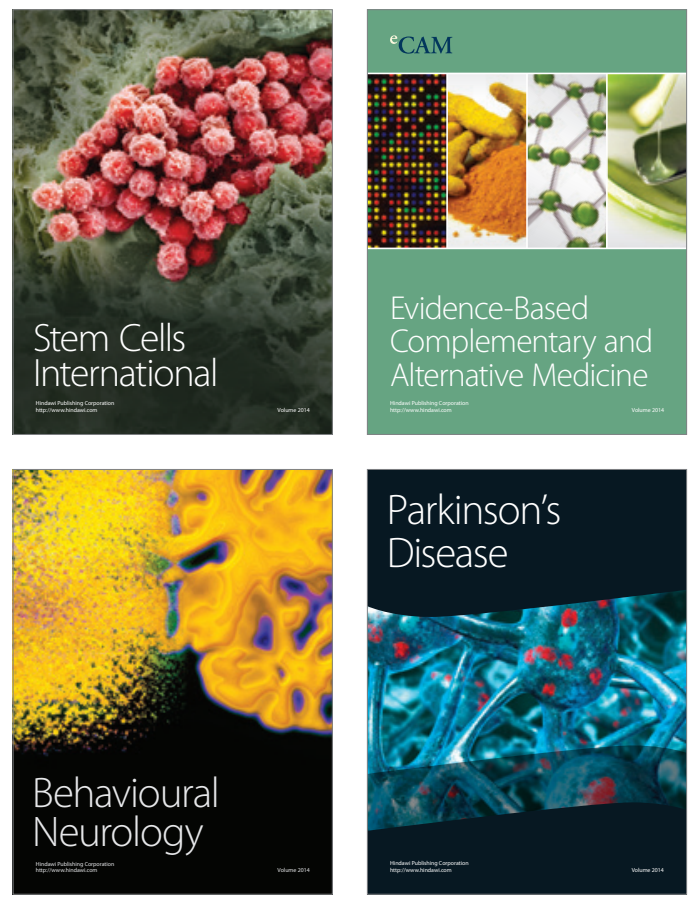
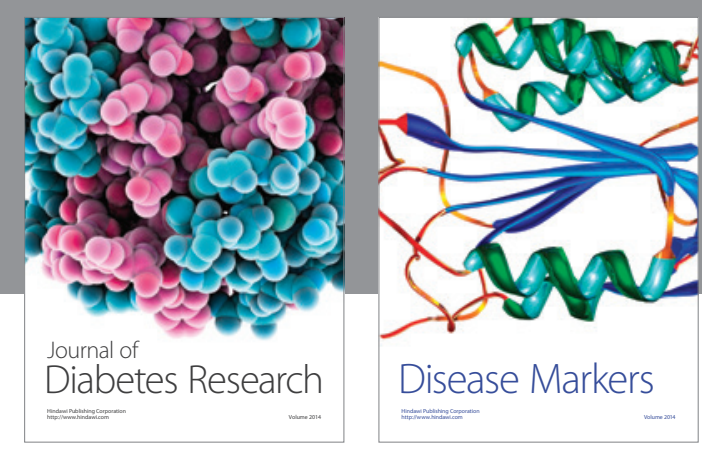

Disease Markers
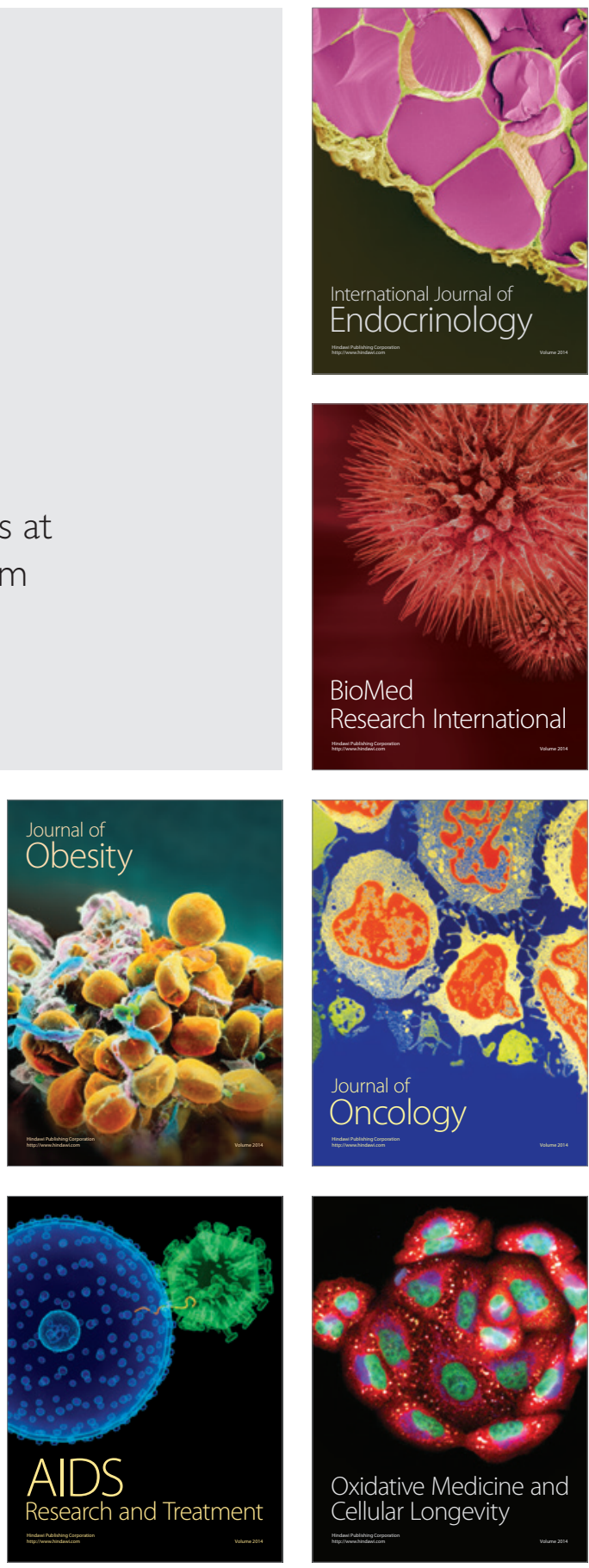